\title{
Has Anyone so far Bridged the Gap between microRNA, Botanicals and Oropharyngeal Squamous Cell Carcinoma?
}

\author{
Mohammed E Grawish ${ }^{1^{\star}}$, Mathias Wagner ${ }^{2}$, Benjamin Vicinus ${ }^{3}$, Michael J Jack ${ }^{4}$, Tereza Richards ${ }^{5}$, Ahmed Ragheb Zaher $^{1}$ and Chen Xi ${ }^{6}$ \\ ${ }^{1}$ Department of Oral Biology, Mansoura University, Egypt \\ ${ }^{2}$ Department of Pathology, Saar State University, Homburg Campus, Homburg Saar, Germany \\ ${ }^{3}$ Department of General, Visceral, Vascular and Paediatric Surgery, Saar State University, Homburg Campus, Homburg Saar, Germany \\ ${ }^{4}$ Competence Centre for Complementary Medicine and Naturopathy, Technical University Munich, Munich, Germany \\ ${ }^{5}$ Medical Library, University of the West Indies, Mona Campus, Kingston, Jamaica, W.I. \\ ${ }^{6}$ Department of Applied Biology and Chemical Technology, Hong Kong Polytechnic University, Hong Hom, Kowloon, Hong Kong
}

*Corresponding author: Grawish ME, Georgetown University School of Medicine, USA, Tel: 202 877-1964; E-mail: Grawish2005@yahoo.com

Rec date: May 06, 2014; Acc date: July 11, 2014; Pub date: July 13, 2014

Copyright: @2014 Grawish ME et al. This is an open-access article distributed under the terms of the Creative Commons Attribution License, which permits unrestricted use, distribution, and reproduction in any medium, provided the original author and source are credited.

\begin{abstract}
Background/Context: Current debate concerning properties of oropharyngeal squamous cell carcinoma (OSCC) is nothing new. More recent information can be found on functional aspects of microRNA (miRNA) in botanicals and mammals, suggesting that the aging process and cancer development are regulated by these molecules. Interestingly, some dietary supplements (especially botanicals) have been reported to have cancer chemopreventive and/or anti-cancer properties and are common ingredients in so-called "anti-aging" creams.
\end{abstract}

Objective: The present study was therefore conducted to determine the state-of-the-art on botanicals, OSCC, and their relationship to miRNA.

Methods/Design: PubMed and Google Scholar were interrogated for articles published in English between January 1, 2000 and December 31, 2010 that discuss botanicals and which could possibly be used in treating OSCC. Additional searches in Google, Google Scholar, PubMed and KoreaMed were conducted to detect possible associations between miRNAs and the aforementioned items.

Results: The current body of literature suggests that botanicals might deliver some of their properties via miRNAs. No report was found however that makes a direct connection to OSCC. It therefore has not been determined whether there is an association between botanicals, OSCC, and miRNA molecules that could possibly have "anti-aging" as well as cancer chemopreventive and/or anti-cancer properties.

Conclusions: Systematic studies are needed to determine whether it is miRNA that could dispense possible therapeutic properties of botanicals on OSCC.

Keywords: Botanicals; miRNA; Oropharyngeal Squamous cell carcinoma

\section{Introduction}

MicroRNAs (miRNAs) are small post-transcriptional regulators found in animals and plants (Figure 1). Numerous miRNA sequences are evolutionarily conserved among plant species $[1,2]$ as are their target sequences in the mRNAs [3]. This could possibly be due to the role of miRNAs in gene expression control. The average half-life of mammalian miRNAs has been calculated to be 119 hours which suggests that they are up to ten times more stable than mRNAs [4]. Among the differences between plant and animal miRNA biology are the processing, the position of target interaction and/or the degree of complementarity [5]. Health related functions may be mediated by miRNAs which regulate the expressome, metabolome or interactome [6] within plants (esp. botanicals) and/or molecules that modify the status of miRNAs within animals (esp. humans). Tanshinone IIA (Chemical Abstracts Service Registry Number, CAS no: 568-72-9) for instance, a constituent of the traditional Chinese medicine Dan shen (Salvia miltiorrhiza; National Center for Biotechnology Information, NCBI, Taxonomy Identifier: 226208) protects against particular variants of sudden cardiac death via repression of miRNA-1 which targets the inwardly rectifying potassium channel subunit Kir2.1 (Universal Protein Resource, UniProt, Identifier: Q64273) [7].

Oropharyngeal squamous cell carcinoma (OSCC, figure 2) has been defined as cancer of the anatomical regions that are covered by the classificators $\mathrm{C} 00-\mathrm{C} 10[8,9]$. It is among the most common cancers worldwide, and continues to represent a public health problem [10]. Despite advances in therapy, cure rates and survival remain poor [11]. OSCC often appears to be preventable and is likely to be related to behavioral and lifestyle factors. Prevention of OSCC therefore remains the goal to reduce the incidence of this disease $[12,13]$.

Anticancerous effects such as growth inhibition of OSCC cell lines can be mediated by miRNAs [14]. It is however noteworthy that some miRNAs can also promote cancer by supporting cell growth or metastasis [15], a phenomenon outside the scope of the present study. 


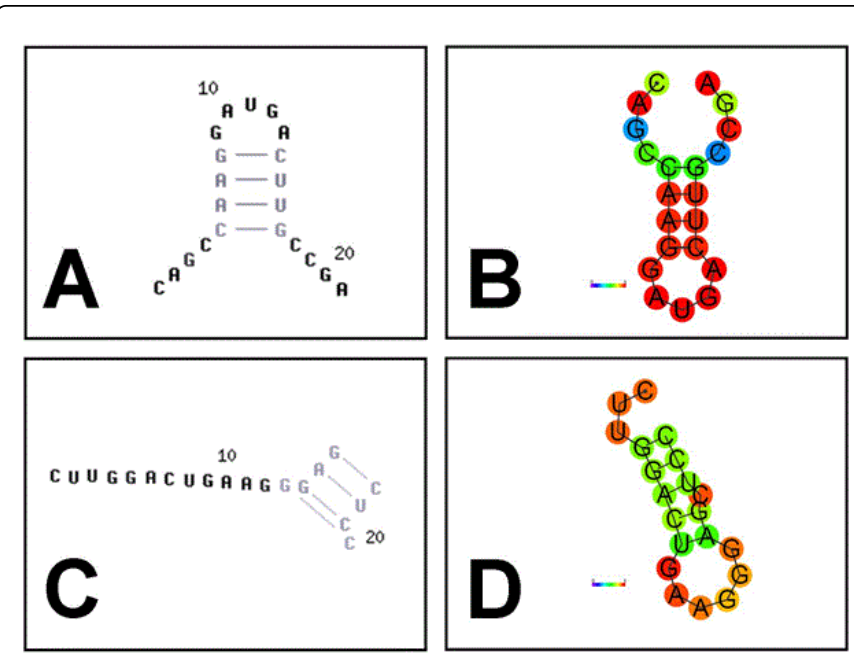

Figure 1: Graphic image representation of miRNA. Exemplarily selected results of single sequence RNA secondary structure prediction experiments for two miRNA species of Solanum lycopersicum, sly-miR169c [157] and sly-miR319 [160]. Two different computer programs, CONTRAfold (version: 2.02) [164] and RNAfold (Vienna RNA package version 2.0.0) [165, 166], were used to allow for visual comparison of geometries. [A] A secondary structure suggested for sly-miR169c based on conditional log-linear models (CLLM; CONTRAfold); [B] Coherence was found for the predicted minimum free energy structures and base pair probabilities for sly-miR169c (RNAfold); [C] A CLLM-based secondary structure suggested for sly-miR319 (CONTRAfold); [D] The secondary structure predicted for sly-miR319 based on minimum free energy structures and base pair probabilities (RNAfold) is not coherent, warranting further research

The use of dietary supplements, especially botanicals, or parts of them such as extracts or seeds as medicines predates recorded history and may be seen to represent an antecedent to modern medicine [16]. Technological advancement has facilitated the delivery of breakthrough bioactive compounds of botanicals with potency more or less comparable to those of conventional drugs [17]. Also their low cost, (per) oral bioavailability, and assumed low-risk profile at pharmacologically relevant concentrations have tremendous appeal. As a result of this assumed safety a considerable number of women for example use herbal remedies during pregnancy [18]. Phytochemicals have been evaluated for cancer chemoprevention and anti-cancer activities, increasingly throughout the course of the past decade [19-22]. Interestingly, some of these botanicals are among the top 10 ingredients in 2010 "anti-aging" creams [23]. This and previous reports [24-28] are suggesting that cancer chemopreventive agents and/or anti-aging drugs could have something in common. What they have in common could be effects mediated by miRNA as these molecules play a role in controlling the aging process [29] and cancer development [30]. It may therefore be hypothesized that botanicals could execute the aforementioned cancer chemopreventive and/or anti-cancer effects via miRNAs. The present study was conducted to determine whether miRNAs are currently seen as a link between botanicals and issues related to solid malignant tumors as exemplified by OSCC.

Google [31,32], PubMed [33], Google Scholar [34] and KoreaMed [35] were interrogated to identify scientific literature of relevance to this topic/area of research. This paper examines what these search engines present when interrogated for articles describing the possible role of miRNA in association with botanicals that have been applied in the context of chemoprevention of OSCC. Information on the role of botanicals in chemoprevention of OSCC published between January $1^{\text {st }}, 2000$, to December $3^{\text {st }}, 2010$, is followed by a summary on miRNAs.

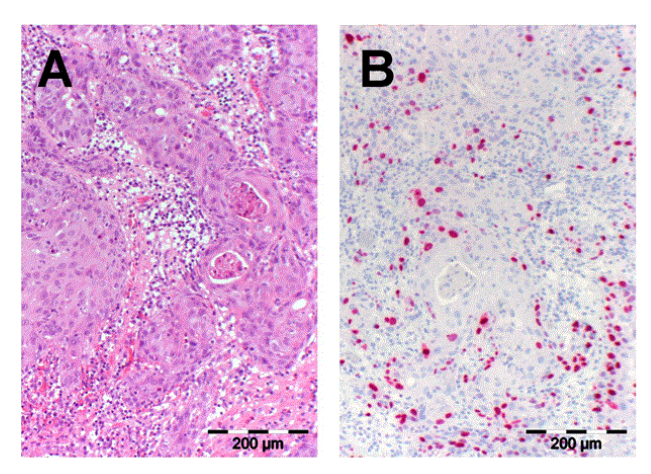

Figure 2: Microscopic image representation of the tumor. Oropharyngeal squamous cell carcinoma as exemplified by a pT1 G2 [9] lesion removed from the mouth floor (C04) of a 52 year old Caucasian male. [A] The histoarchitectonic pattern (Hematoxylin and Eosin, H\&E, stain); [B] Late G1, S, M and G2 cell cycle phase (bright red signal), tumor cell nuclei, immunohistochemically contaminated with monoclonal mouse anti-human antibodies to the Ki67 antigen (clone: Mib1; Dako Deutschland $\mathrm{GmbH}$, Hamburg, Germany; dilution: 1:100; BenchMark Series immunostainer, ultraView Universal Alkaline Phosphatase Red Detection Kit 760-501; Ventana Medical Systems, Inc., Tucson, AZ, USA)

\section{Leaves of the trees and shrubs}

\section{Olive tree leaves}

Olive tree (Olea europaea L; NCBI Taxonomy ID: 4146) leaves are well known as a traditional anti-diabetic and anti-hypertensive herbal drug [36]. Extracts rich in oleuropein (CAS no: $32619-42-4,3 \mathrm{mg} / \mathrm{kg}$ body weight; bw) inhibited carcinogenesis in the oropharynx of Rattus norvegicus (NCBI Taxonomy ID: 10116), type Fischer (F344), after inductive treatment with 4-Nitroquinoline 1-oxide (4-NQO) (CAS no: 56-57-5) [37].

\section{Neem tree leaves, flowers and fruits}

Neem (Azadirachta indica; NCBI Taxonomy ID: 124943) is a versatile tree of family Meliaceae (NCBI Taxonomy ID: 43707), the antiproliferative activity of neem tree flowers against some cancer cell lines was established [38]. Ethanolic neem leaf extract $(200 \mathrm{mg} / \mathrm{kg} \mathrm{bw})$ and neem leaf fractions $(1,10,100 \mathrm{mg} / \mathrm{kg} \mathrm{bw}$, in a dose dependent manner, ddm) have been reported to inhibit the development of OSCC in the buccal pouch of hamsters (NCBI Taxonomy ID: 10036) after application of 7,12-Dimethylbenz(a)anthracene (DMBA) (CAS no: 57-97-6) [39,40]. Apoptosis induction in neem treated hamsters was mediated by the expression of Bim (UniProt: Not Available), Bcl-2 (UniProt: Q687E0), caspase 3 (UniProt: Q60431), and caspase 8 
Citation: Grawish ME, Wagner M, Vicinus B, Jack MJ, Richards T, et al. (2014) Has Anyone so far Bridged the Gap between microRNA, Botanicals and Oropharyngeal Squamous Cell Carcinoma?. Altern Integ Med 3: 163. doi:10.4172/2327-5162.1000163

Page 3 of 11

(UniProt: Not Available) [41]. The neem fruit limonoids azadirachtin (CAS no: $11141-17-6 ; 10,100 \mu \mathrm{g} / \mathrm{kg}$ bw) and neem flower nimbolide (CAS no: $25990-37-8 ; 10,100 \mu \mathrm{g} / \mathrm{kg}$ bw) appeared to block cell proliferative activity and induce apoptosis. Comparatively, nimbolide is a more potent antioxidant and cancer chemopreventive agent [42, 43].

\section{Green, black and yerba mate shrub tea leaves}

Tea, from the plant Camellia sinensis L. (NCBI Taxonomy ID: 4442), is one of the most common beverages and is generally consumed in its green, black, or oolong form. The main tea extract components are tea polyphenols and tea polysaccharides [44]. Green tea extract (GTE, $0.6 \%$ solution in tap water) and curcumin (CAS no: 458-37-7; $10 \mu \mathrm{mol})$ [45] had anticancerogenic effects by apoptosis induction, and the inhibition of cell proliferation and angiogenesis. It was proposed that green tea polyphenols (CAS no: 84650-60-2; 200 $\mathrm{mg} / \mathrm{kg}$ bw/day) may act as a detoxifying agent, altering the expression of glycoconjugates and immunological markers [46], modulating lipid peroxidation and enhancing antioxidant ability [47] in an OSCC model. The recent effect was also associated with black tea polyphenols (BTP, CAS no: 84650-60-2; 0.05\% Polyphenon) [47].

Epigallocatechin-3-gallate (CAS no: $989-51-5 ; 0$ to $60 \mu \mathrm{M}$ or 5,10 , $20,50 \mu \mathrm{M}, \mathrm{ddm})$ of green tea decreased the expression of matrix metalloproteinase (MMP) 2 (UniProt: P08253) and 9 (UniProt: P14780), urokinase plasminogen activator (UPA; UniProt: P00749) and inhibited the invasion and migration of carcinoma HSC-2 cells and normal HGF-2 fibroblasts cells [48-50]. A phase II randomized, placebo-controlled trial of GTE $\left(500,750\right.$, or $\left.1,000 \mathrm{mg} / \mathrm{m}^{2}, \mathrm{ddm}\right)$ concluded that GTE may suppress oropharyngeal premalignant changes, in part by reducing angiogenic stimulation [51].

Black tea was confirmed to have a beneficial effect on oropharyngeal leukoplakia (OLP) [52]. The BTP (30 to $40 \mathrm{mg} / \mathrm{kg} \mathrm{bw}$ ) exerted its preventive effects by inhibiting cell proliferation, modulating the oxidant-antioxidant status as well as markers of cell proliferation, cell survival, tumor infiltration, angiogenesis, apoptosis and xenobiotic-metabolizing enzymes [53-55]. The dietary administration of solitary or combined bovine lactoferrin (UniProt: Q6LBN7; 0.2\%) and/or BTP (0.05\% Polyphenon-B) has been reported to reduce tumor incidence in the hamster buccal pouch (HBP) [56]. Yerba mate tea (236 to $490 \mathrm{mg}$ equiv of chlorogenic/g of dry leaves) is rich in phenolic constituents and can inhibit OSCC proliferation, topoisomerase 1 (UniProt: P11387), topoisomerase 2 (UniProt: P11388) [57].

\section{Seaside clerodendron shrub leaves}

Seaside Clerodendron (Clerodendrum inerme, NCBI Taxonomy ID: 49994) is an evergreen sprawling shrub 1-1.8 $\mathrm{m}$ tall, containing two sterol constituents [58]. It was found that peroral administration of Clerodendron inerme aqueous leaf extract $(500 \mathrm{mg} / \mathrm{kg} \mathrm{bw})$ reduced the incidence and size of DMBA-induced OSCC in the HBP [59].

\section{Roots, rhizomes and barks of shrubs herbaceous and trees}

\section{Ashwaghanda shrub roots}

Ashwaghanda (Withania somnifera; NCBI Taxonomy ID: 126910) root extracts are commonly used in Indian traditional Ayurveda as a general tonic for overall health and remedy for a variety of ailments [60]. Withaferin-A (CAS no: 5119-48-2; $20 \mathrm{mg} / \mathrm{kg}$ bw), a steroidal lactone isolated from Withania somnifera, appeared to prevent alterations of both p53 (UniProt: Q00366) and Bcl-2 and decreases micronucleus formation in the bone marrow once administered to DMBA-painted hamsters [61,62]. Withaferin-A prevented tumor formation and helped maintain erythrocyte integrity during DMBA induction of OSCC [63].

\section{Curcumin and ginger herbaceous plant rhizomes}

Curcumin (diferuloylmethane), a polyphenol from the plant Curcuma longa (NCBI Taxonomy ID: 136217), traditionally called turmeric is used for cancer chemoprevention and treatment [64]. Meanwhile, ginger (Zingiber officinale; NCBI Taxonomy ID: 94328) is one of the plants family members that includes cardamom (NCBI Taxonomy ID: 105181) and turmeric [65]. Curcumin (0.1, 1.0, 10.0 $\mu \mathrm{M}, \mathrm{ddm}$ ) was considerably more potent than genistein (CAS no: 446-72-0) isoflavone and quercetin (CAS no: 117-39-5) flavonoid, but cisplatin (ATC/DDD: L01XA01; a platinum-based chemotherapy drug; CAS no: 15663-27-1) was fivefold more potent than curcumin in inhibition of growth and DNA synthesis in a cell line (SCC-25) in vitro [66]. In metabolism studies, curcumin $(1,5,10,25$, and $50 \mu \mathrm{M}, \mathrm{ddm})$ inhibited P-450 1A1 (UniProt: P04798)-mediated by benzo(a)pyrene diol (CAS no: 51689-89-5) bioactivation in both OSCC lines and intact oropharyngeal mucosa [67]. Curcumin $(0.1 \mu \mathrm{M}$ to $1 \mathrm{mM})$ could also induce reactive oxygen species generation and early apoptotic changes in human gingival fibroblasts and human submandibular gland carcinoma cells [68]. It was reported that peroral administration of curcumin $(80 \mathrm{mg} / \mathrm{kg} \mathrm{bw})$ and piperine (CAS no: $94-62-2 ; 50 \mathrm{mg} / \mathrm{kg}$ bw) to DMBA-painted hamsters helped prevent the formation of OSCC [69].

Moreover, dietary turmeric (1\%) augmented apoptosis and decreased cell proliferation in DMBA-treated animals, reflected by decreased tumor burden, multiplicity and enhanced latency period [70]. In highly invasive human YD-10B OSCC cell lines, curcumin inhibited cell proliferation and motility through decreased expression of MMP2 and 9, UPA and UPA receptor (UniProt: Q03405) [71].

Ginger (400 mg powder added to labarotory chow) might have a preventive effect on oropharyngeal carcinogenesis through induction of apoptosis and suppression of tumor growth and proliferation [72].

\section{Portia tree barks}

Portia tree or Thespesia populnea Soland ex Correa (NCBI Taxonomy ID: 3638; Family: Malvaceae; NCBI Taxonomy ID: 3629) is a large tropical tree found in coastal forests and India [73]. Ethanolic extract of Thespesia populnea bark ( $300 \mathrm{mg} / \mathrm{kg} \mathrm{bw}$ ) has been reported to execute cancer preventive effects in HBP contaminated with DMBA [74].

\section{Fruits and their seeds}

\section{Black raspberries}

Black raspberries (Rubus occidentalis; NCBI Taxonomy ID: 75079) contain many compounds with both in vitro and in vivo preventive properties [75]. The lyophilized black raspberries (5\% and 10\%) had a preventive activity and inhibited the tumor formation in the oral cavity [76]. Black raspberries inhibitory effects on growth of dysplastic 
Citation: Grawish ME, Wagner M, Vicinus B, Jack MJ, Richards T, et al. (2014) Has Anyone so far Bridged the Gap between microRNA, Botanicals and Oropharyngeal Squamous Cell Carcinoma?. Altern Integ Med 3: 163. doi:10.4172/2327-5162.1000163

Page 4 of 11

human cells from the oropharynx were attributed to certain components that target specific signaling pathways regulating the progression of cell cycle [77]. Ethanolic extract $(10,50,100 \mu \mathrm{g} / \mathrm{ml}$, $\mathrm{ddm}$ ) of freeze-dried black raspberries was a promising agent for prevention of oropharyngeal epithelial dysplasia [75]. Application of black raspberry bioadhesive gel $(10 \% \mathrm{w} / \mathrm{w}$ gel or $0.5 \mathrm{~g}$ of $10 \%$ gel $)$ containing anthocyanins (CAS no: 15067-77-7) represented a promising strategy for human OSCC chemoprevention by modulation of gene expression and reduction of cyclooxygenase-2 (UniProt: Q9NNY7) protein [78,79].

\section{Cranberry and grape seeds}

Cranberries (Vaccinium macrocarpon; NCBI Taxonomy ID: 13750) are a group of evergreen dwarf shrubs often used by pregnant or breastfeeding women as a preventive agent against urinary tract infections [80]. Grapes (Vitis vinifera; NCBI Taxonomy ID: 29760) are considered the world's largest fruit crops, with an approximate annual production of 58 million metric tons [81]. Grape seeds are rich sources of monomeric phenolic compounds, such as catechins (CAS no: 7295-85-4), epicatechin (CAS no: 490-46-0) and epicatechin-3-Ogallate (CAS no: 1257-08-5) and dimeric, trimeric and tetrameric procyanidins (CAS no: 4852-22-6) acting as antimutagenic and antiviral agents [82]. Grape seed proanthocyanidins (CAS no: 84929-27-1) differ from cranberry proanthocyanidins in that they are more likely to contain galloylated flavan-3-ols, and the monomers are primarily B linked [83]. Extracts of grape seed were more cytotoxic than grape peel extracts and $70 \%$ methanol extracts of grape seed selectively killed two human oropharyngeal tumor cell lines [84]. Cranberry and grape seed extracts (both 10 to $80 \mu \mathrm{g} / \mathrm{ml}$, ddm) inhibited the proliferation of OSCC cell lines (CAL27 and SCC25) in a dose-dependent manner [85].

\section{Tomato and its orange colored lycopene}

Tomato is an edible fruit of the plant Solanum lycopersicum (NCBI Taxonomy ID: 4081) [86]. Combined administration of tomato (0.25 mg lycopene/ml; CAS no: 502-65-8;) and garlic (NCBI Taxonomy ID: $4682 ; 12.5 \mathrm{mg} / \mathrm{ml}$ ) inhibited the development of OSCC in the HBP by downregulation of $\mathrm{Bcl}-2$ and upregulation of Bax (UniProt: Not Available), Bim, P53 and the caspases 3 and 8 [87]. They modulated xenobiotic-metabolizing enzymes mitigating the mutagenic and carcinogenic effects of DMBA [88]. Lycopene (a red carotene found in tomatoes; $2.5 \mathrm{mg} / \mathrm{kg}$, bw) might exert its preventive effects by modulating lipid peroxidation and enhancing the activities of the enzymes in the glutathione redox cycle as it reduced glutathione (GSH; CAS no: 70-18-8), glutathione peroxidase (GPx; UniProt: P86215), glutathione S-transferase (GST; UniProt: P30116) and glutathione reductase (UniProt: Not Available) as biomarkers of cancer chemoprevention [89]. Lycopene (3 and $7 \mathrm{~mol} / \mathrm{L})$ inhibited proliferation and enhanced gap-junction communication of KB-1 tumor cells from the human oropharynx [90]. The observed effect of lycopene ( 4 or $8 \mathrm{mg}$ /day) suggested that it can be effectively and safely used for the management of OLP [91]. Tomato paste containing weight lycopene $(5 \mathrm{mg} / \mathrm{kg}$ bw reduced the incidence of OSCC in the HBP [92].

\section{Flavors and Spices}

\section{Garlic and its water soluble extract S-allylcysteine}

Garlic (Allium sativum L. fam. Allioideae; Taxonomy ID: 40553) is one of the most commonly used spices and herbal remedies. Alliinase (UniProt: D2CXF2), alliin (sulfur-containing compounds, CAS no: 556-27-4), and allicin (compounds produced enzymatically from alliin, CAS no: 539-86-6) are the main constituents of garlic [93]. Administration of S-allylcysteine (CAS no: 21593-77-1; $200 \mathrm{mg} / \mathrm{kg} \mathrm{bw}$ ) or aqueous garlic extract $(250 \mathrm{mg} / \mathrm{kg} \mathrm{bw}$ ) suppressed DMBA-induced oropharyngeal carcinogenesis as revealed by the absence of neoplasms, induction of transglutaminase (UniProt: Not Available) and inhibition of Bcl-2 expression and restored retinoic acid receptor-beta mRNA (UniProt: Q8VHB7) expression to normal [94-97]. S-allylcysteine (0, $2,510,20 \mathrm{mM}$, ddm) effectively inhibited the proliferation, upregulated the expression of E-cadherin (UniProt: Q9UII7) molecule and stabilized the E-cadherin/beta-catenin (UniProt: P35222) adherent junction complex in human OSCC cell lines [98]. Altered cytokeratin expression and enhanced quantities of circulatory antioxidants were suggested to be associated with garlic-mediated cancer chemoprevention $(250 \mathrm{mg} / \mathrm{kg} \mathrm{bw})$ of experimental OSCC in the HBP $[99,100]$.

In 4NQO-induced rat tongue carcinogenesis, garlic $(25 \mathrm{mg} / \mathrm{ml})$ might execute its preventive effects by modulating lipid peroxidation and enhancing the levels of GSH, GPx (UniProt: P04041) and GST (UniProt: Q6LDP3) [101].

\section{Pepper and its ingredients (piperine and capsaicin)}

Piperine (CAS no: 94-62-2) extracted from Piper longum (long pepper; NCBI Taxonomy ID: 49511) and Piper nigrum (black pepper; NCBI Taxonomy ID: 13216) is an active alkaloid, consumed by a large number of individuals worldwide [102]. Piperine (50 mg/kg bw) had been suggested to execute a chemopreventive effect on DMBAmediated induction of OSCC in the HBP [103]. The modifying effects of dietary capsaicin (CAS no: 404-86-4; ATC/DDD: N01BX04; active component of chili peppers; NCBI Taxonomy ID: 4073; 500 ppm, $\mathrm{w} / \mathrm{w}$ ) and rotenone (CAS no: $83-79-4 ; 500 \mathrm{ppm}$ ) on initiation or promotion phase of 4-NQO-induced rat tongue carcinogenesis reduced the frequency of OSCC [104].

\section{Plants used in Traditional Chinese Medicine}

Levamisole (CAS no: 14769-73-4; ATC/DDD: P02CE01; antihelminthic drug) and/or Chinese medicinal herbs (root of Astragalus, NCBI Taxonomy ID: 20400; 12 g/day; fruit of Ligustrum, NCBI Taxonomy ID: 104487; 9 g/day; and fruit of Ziziphi jujuba; NCBI Taxonomy ID: 157914; 9 g/day) can modulate the level of the serum SCC associated antigen. For OLP patients, the combination therapy was superior to the single therapy of levamisole or of Chinese medicinal herbs [105]. Chinese herbal extracts of Drynaria bonii (NCBI Taxonomy ID: 272673), Angelica sinensis (NCBI Taxonomy ID: 165353) and Cornus officinalis Sieb (NCBI Taxonomy ID: 16906) were investigated for their antitumor potential on human OSCC cell lines (HSC-2 and NA) and the data demonstrated several unique antitumor properties of Drynaria bonii [106].

Ching waysan $(0,10,25,50,75$ and $100 \mu \mathrm{l} / \mathrm{ml}$, ddm; table 1) induced apoptosis via a Bax (UniProt: Q07812)-dependent pathway in human OSCC cell lines (OC2 and TSCCa) [107]. Shenyang (1,026 mg 
Citation: Grawish ME, Wagner M, Vicinus B, Jack MJ, Richards T, et al. (2014) Has Anyone so far Bridged the Gap between microRNA, Botanicals and Oropharyngeal Squamous Cell Carcinoma?. Altern Integ Med 3: 163. doi:10.4172/2327-5162.1000163

Page 5 of 11

or $256.5 \mathrm{mg} / 100 \mathrm{~g} \mathrm{bw}$ ) had immune modulatory effects in rattus norvegicus, Sprague-Dawley type, with 4-NQO-induced OSCC [108]. Zeng sheng ping $(6 \mathrm{~g} / \mathrm{kg}$ bw/day by gavage) has been reported to prevent OSCC in humans with OLP as well as in animal models [109].

Herba erigerontis (NCBI Taxonomy ID: 124940) appeared to hamper the possible progression of OLP to tumor [110]. Also, Xian huayin $(1.7 \mathrm{ml}$ or $11.4 \mathrm{ml} / \mathrm{kg}$ bw/day) from China may exhibit a reversal effect on DMBA-induced premalignant lesions in the HBP [111]. The extract of the rhizome of Coptidium (NCBI Taxonomy ID: $568508,13.5 \% \mathrm{w} / \mathrm{w}$ ) induced cytochrome-c (UniProt: P99999) dependent apoptosis in immortalized and malignant human oropharyngeal keratinocytes via the mitochondrial signaling pathway [112].

Verticinone (CAS no: 18059-10-4; different concentrations for different cell lines), an alkaloid from Fritillaria ussuriensis (NCBI Taxonomy ID: 152096) induced apoptosis through a caspase pathway mediated by mitochondrial damage in immortalized keratinocytes and OSCC cell lines [113]. Rhein (CAS no: 478-43-3) is a anthraquinone (CAS no: 84-65-1) compound from Rheum palmatum (NCBI Taxonomy ID: $137221 ; 0,25,50,100 \mu \mathrm{M}$ ) having inhibitory effects on OSCC as do emodin (CAS no: 518-82-1; 0, 20, 30, $40 \mu \mathrm{M}$ ) and aloeemodin (CAS no: $481-72-1 ; 2.5,5,10,20,40 \mu \mathrm{M}$ or $0,25,50,100 \mu \mathrm{M}$ ) [114,115]. Shikonin (CAS no: 517-89-5; 0, 10, 20, 30, $40 \mu \mathrm{M}$, ddm), a naphthoquinone (CAS no: 130-15-4) pigment, seemed to alter growth and induce apoptosis in the human OSCC cell line Tca-8113 [116].

\section{Algae and their Extracts}

\section{Spirulina platensis}

Spirulina (NCBI Taxonomy ID: 1154) is a blue-green filamentous alga (NCBI Taxonomy ID; 1117) [117]. Spirulina platensis (Arthrospira platensis, NCBI Taxonomy ID: 118562; 10 mg/day) inhibited dysplastic changes occurring in the HBP mucosa and had a long-term cancer regression role on DMBA-induced OSCC $[118,119]$.

\section{Miscellaneous Compounds}

\section{Ferulic acid}

Ferulic acid (hydroxycinnamic acid, CAS no: 1135-24-6), is found in the brans of grasses such as wheat (Triticum aestivum; NCBI Taxonomy ID: 4565), rice (Oryza sativa; NCBI Taxonomy ID: 4530), and oats (Avena; NCBI Taxonomy ID: 4496) [120]. It (40 mg/kg bw) has been said to reduce tumor incidence and size in DMBA-painted animals by exhibiting antilipidperoxidative effects as well as its ability to modulate the status of carcinogen detoxifying agents [121].

\section{Carnosic acid}

Carnosic acid (CAS no: 3650-09-7; $10 \mathrm{mg} / \mathrm{kg}$ bw/day) from rosemary (Rosmarinus officinalis; NCBI Taxonomy ID: 39367) has been suggested to chemoprevent against DMBA-induced OSCC possibly due to likely carcinogen detoxification and antilipidperoxidative properties [122].

\section{Berberine}

Berberine (CAS no: 2086-83-1), an isoquinoline (CAS no: 119-65-3) alkaloid present in roots, rhizome and stembark of a number of traditional medicinal plants such as Berberis aquifolium (NCBI Taxonomy ID: 203270), Berberis vulgaris (NCBI Taxonomy ID: 258209), Berberis aristata (NCBI Taxonomy ID: 659592) and Tinospora cordifolia (NCBI Taxonomy ID: 285590)[123]. The tumor size in xenograft mice treated with berberine $(10 \mathrm{mg} / \mathrm{kg}$ bw $)$ was smaller than that in the non-treated control group [124]. Prolonged exposure of human HSC-3 OSCC cell lines to berberine $(0,5,10,25$, $50,75 \mu \mathrm{M})$ increased apoptosis through reduced levels of MMP (UniProt: P03956), release of cytochrome $c$ and activation of caspase 3 (UniProt: P42574) [125]. Moreover, berberine $(0,62.5,100 \mu \mathrm{M})$ was found to down-regulate u-PA, MMP2 and MMP9 expression in SCC-4 cells through the focal adhesion kinase 1 (UniProt: Q05397), inhibitor of nuclear factor (NF) kappa B and NF kappa B mediated pathways and berberine inhibited the invasive capacity of malignant cells [126].

\section{A Few Notes on Dosages}

Additional searches were conducted to compare the dosages previously discussed in cell line and animal models with those suggested for humans. The following databases have been interrogated: About Herbs, a web site provided by the Memorial Sloan Kettering Cancer Center (MSKCC Integrative Medicine Service) [127], Herbs at a Glance, and the Complementary and Alternative Medicine (CAM) subset of PubMed both of which have been established by the National Center for Complementary and Alternative Medicine (NCCAM) [128].

This part of the study revealed that the current body of literature contains only few peer reviewed articles on effective clinical dosages in humans specified by good scientific practice experimental design. At least in parts this may be attributable to the fact that botanicals come in a variety of dosage forms such as teas, creams, gels, capsules or tablets, and/or that they can be formulated for various types of drug delivery supporting extended, sustained or other modes of drug release. Different dosages can therefore be readily extracted from the body of literature (table 1). Comparative studies are warranted to learn more about dose-response relationships in this context.

\begin{tabular}{|c|c|c|c|}
\hline Botanical & Cell Lines & Animal model & Clinical Trial \\
\hline Tea & 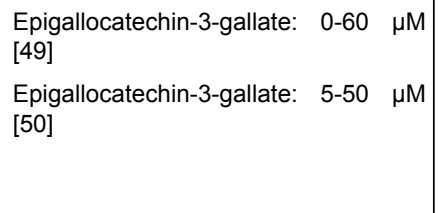 & $\begin{array}{l}\text { Green Tea Extract: } 0.6 \% \text { in tap water [45] } \\
\text { Polyphenols: } 200 \mathrm{mg} / \mathrm{kg} \text { bw [46] } \\
\text { Polyphenon: } 0.05 \%[47,56] \\
\text { Black Tea Polyphenon: } 30-40 \mathrm{mg} / \mathrm{kg} \text { bw [54] } \\
\text { Yerba Mate Tea: } 236-490 \mathrm{mg}[57]\end{array}$ & $\begin{array}{l}\text { Green Tea Extract: } 500,750,1000 \mathrm{mg} / \mathrm{m}^{2} \\
\text { [51] } \\
\text { §Catechin: } 250 \mathrm{mg} / \text { day [167] }\end{array}$ \\
\hline
\end{tabular}




\begin{tabular}{|c|c|c|c|}
\hline Curcumin & $\begin{array}{l}\text { Curcumin: } 0.1,1.0 \text { or } 10.0 \mu \mathrm{M}[66] ; 1, \\
5,10,25, \text { and } 50 \mu \mathrm{M}[67] ; 0.1 \mu \mathrm{M} \text { to } \\
1 \mathrm{mM}[68]\end{array}$ & $\begin{array}{l}\text { Curcumin: } 80 \text { mg/kg bw [69] } \\
\text { Turmeric: } 1 \%[70]\end{array}$ & $\begin{array}{l}\text { §Curcumin: } 8 \mathrm{~g} / \text { day [168]; } 3.6 \mathrm{~g} / \text { day [169]; } \\
\text { 1-4 g/day [170] }\end{array}$ \\
\hline Black Raspberries & $\begin{array}{l}\text { Ethanolic extract: } 10,50 \text { or } 100 \mu \mathrm{g} / \mathrm{ml} \\
\text { [75] }\end{array}$ & $\begin{array}{l}\text { Lyophylized: } 5 \% \text { or } 10 \%[76] \\
\text { Bioadhesive Gel: } 1 \mathrm{~g} \text { of } 5 \% \text { gel }[78]\end{array}$ & Bioadhesive Gel: $0.5 \mathrm{~g}$ of $10 \%$ gel [79] \\
\hline $\begin{array}{l}\text { Tomato/ } \\
\text { Lycopene }\end{array}$ & Lycopene: 3 and 7 mol/L [90] & $\begin{array}{l}\text { Lycopene: } 0.25 \mathrm{mg} / \mathrm{ml} \text { [87]; } 2.5 \mathrm{mg} / \mathrm{kg} \text { bw [89]; } 5 \\
\mathrm{mg} / \mathrm{kg} \text { bw [92] }\end{array}$ & $\begin{array}{l}\text { Lycopene: } 4 \text { or } 8 \mathrm{mg} / \text { day [91] } \\
\text { §Lycopene: } 15 \mathrm{mg} / \text { day [171]; } 4-30 \mathrm{mg} / \text { day } \\
\text { [172] }\end{array}$ \\
\hline Garlic & S-allylcysteine: 0, 2, 5 10, 20 mM [98] & $\begin{array}{l}\text { S-allylcyteine: } 200 \mathrm{mg} / \mathrm{kg} \text { bw [94]; } 250 \mathrm{mg} / \mathrm{kg} \text { bw } \\
\text { [96-100]; } 25 \mathrm{mg} / \mathrm{ml} \text { [101] }\end{array}$ & $\begin{array}{l}\text { §Garlic: } \sim 3.5 \mathrm{~g} / \text { weak (range } 0 \text { to }>28.8 \mathrm{~g} / \\
\text { weak) [173] }\end{array}$ \\
\hline
\end{tabular}

Table 1: Dosage Variations. Differences in dosage and pharmaceutical formulation as exemplified above contribute to making systematic and reliable comparative evaluation a considerable challenge. The superscripted section sign ("\$") marks entries on lesions other than OSCC

\section{MicroRNA}

Medicinal plants may exert the carcinogenic potential by modulating carcinogen detoxification, inhibiting lipid peroxidation, or by improving in vivo antioxidants defense mechanism [90]. Only a few of the described botanicals exhibit articles which describe a role of miRNAs in the corresponding plants. Interrogating PubMed on July $2^{\text {nd }} 2011$ for entries containing for example the search terms "Salvia miltiorrhiza" and "miRNA" produced only a single hit, a publication mentioning the application of real-time reverse transcription polymerase chain reaction to determine the level of miRNA-1[7]. Entering "Salvia miltiorrhiza" and "miRNA" yielded no findings.

In Camellia sinensis there are around 13 conserved miRNAs which belong to 9 miRNA families [129]. Computational homology search in expressed sequencing tags revealed four candidate miRNAs from four miRNA families together with their target [130].

Computational predictions of Vitis vinifera genome identified 5.778 putative miRNAs [131]. High-throughput sequencing in Vitis vinifera tagged 24 conserved miRNA families, 26 non-conserved miRNA families and 21 grapevine-specific miRNAs [132]. Several grape genes contain putative binding sites of miRNAs [133]. Differential miRNA patterns in tissue development and fruit maturation indicate a function of miRNAs in these processes [134].

In Solanum lycopersicum 78 highly conserved mature miRNAs were found by a miRNA detecting microarray [135] and miRNAs play a role in the symbiosis with arbuscular mycorrhizal [136] and draught response (miRNA-169c) [137]. The miRNAs-159[138], 164 [139] and 319 [140] are involved in mechanisms like stamen regulatory network or leaf and flower development of Solanum lycopersicum.

In tomato plants the miRNA network is also associated with viral infection and is involved in: host defense response [141], altered host miRNA expression [142] and thereby miRNA mediated gene expression [143].

In safflower at least 236 miRNAs were identified which show different expression patterns in different tissues [144].

High throughput sequencing of wheat small RNAs revealed 58 miRNAs of 43 families from which 4 new miRNAs seem to be specific for monocots [145]. In the Triticeae 28 miRNA precursors were identified together with 337 target sequences in genes [146].

Approximately 40 potential miRNA genes were found in Oryza sativa [147]. Altered miRNA expression in rice was found as a result of heavy metal stress [148] and other biotic and abiotic stress factors [149]. Rice miRNAs control transcription factors which are involved in development and genes that regulate physiological processes [150].

Little is known about botanicals possibly inducing miRNAs in humans. Treatment of carcinoma cells with green tea polyphenons (polyphenon-60 or epigallocatechin gallate) leads to altered expression of miRNAs [151,152]. Epigallocatechin gallate changed miRNA expression in Hep G2 cells [153] and deregulated miRNA-21 and miRNA-330 in a mouse model of prostate carcinoma [154]. In a model of myocardial infarction miRNA-1 was downregulated by Tanshinone IIA a bioactive component of Salvia miltiorrhiza [7].

Curcumin up-regulated miRNA-15a and miRNA-16 in MCF-7 breast carcinoma cells and induced apoptosis of A549 human lung carcinoma cells by targeting miRNA-186 ${ }^{\star}[155-157]$. In pancreatic carcinoma cell lines miRNA-200 and miRNA-22 were up-regulated and miRNA-21 and miRNA-199* were down-regulated by curcumin (and its analogue CDF) [158,159]. Down-regulation of miRNA-21 by curcumin also inhibited invasion and metastasis in a chicken-embryometastasis model [160]. miRNA-146a and IRAK-2 were downregulated by curcumin in stressed human astroglial cells in primary culture and a mouse model of Alzheimer's disease [161,162].

Extracts of Chinese herbal plant Coptidis rhizoma up-regulated miRNA-21 and miRNA-23a in human liver carcinoma cells (MHCC97-L) [163].

For the botanicals, ingredients, and properties that are not listed in this review, because there were no articles found which described the role of miRNAs in the plant or changes in human/animal miRNA expression upon treatment.

\section{Conclusion}

Botanical and nutritional compounds have been used for the treatment of cancer throughout human history. So far little is known about the impact of miRNA on expression and function of botanicals. Nevertheless few studies indicate that miRNAs could mediate their health associated processes. Systematic studies are now warranted to determine their role in the chemoprevention of OSCC. To the knowledge of the authors no studies have so far directly bridged the gap between miRNA, botanicals, and the chemoprevention of OSCC. It remains therefore unclear if there is an association between botanicals, OSCC, and miRNA molecules that could possibly have 
"anti-aging" as well as cancer chemopreventive and/or anti-cancer properties.

\section{References}

1. Axtell MJ, Bartel DP (2005) Antiquity of microRNAs and their targets in land plants. Plant Cell 17: 1658-1673.

2. Zhang B, Pan X, Cannon CH, Cobb GP, Anderson TA (2006) Conservation and divergence of plant microRNA genes. Plant J 46: 243-259.

3. Floyd SK, Bowman JL (2004) Gene regulation: ancient microRNA target sequences in plants. Nature 428: 485-486.

4. Gantier MP, McCoy CE, Rusinova I, Saulep D, Wang D, et.al (2011) Analysis of microRNA turnover in mammalian cells following Dicer1 ablation. Nucleic Acids Res

5. Lelandais-Brière C, Sorin C, Declerck M, Benslimane A, Crespi M, et.al (2010) Small RNA diversity in plants and its impact in development. Curr Genomics 11: 14-23.

6. Bakry R, Rainer M, Huck CW, Bonn GK (2009) New stationary phases for enrichment and separation in the 'omics' era. Bioanalysis 1: 151-169.

7. Shan H, Li X, Pan Z, Zhang L, Cai B et al (2009) Tanshinone IIA protects against sudden cardiac death induced by lethal arrhythmias via repression of microRNA-1. Br J Pharmacol 158: 1227-1235.

8. Sankaranarayanan R, Dinshaw K, Nene BM, Ramadas K, Esmy PO, et al (2006) Cervical and oral cancer screening in India. J Med Screen 13: S 35-38.

9. Wittekind $\mathrm{CH}$, Meyer HJ, Bootz F (2010) TNM-Klassifikation maligner Tumoren. 7th (edn) Springer-Verlag GmbH Berlin, Heidelberg, New York, London, Tokyo.

10. Warnakulasuriya S. (2010) Living with oral cancer: epidemiology with particular reference to prevalence and life-style changes that influence survival. Oral Oncol 46: 407-410.

11. Silverman S Jr, Kerr AR, Epstein JB (2010) Oral and pharyngeal cancer control and early detection. J Cancer Educ 25: 279-281.

12. Day TA, Davis BK, Gillespie MB, Joe JK, Kibbey M, et al (2003) Oral cancer treatment. Curr Treat Options Oncol $4: 27-41$.

13. Saunders FR, Wallace HM (2010) On the natural chemoprevention of cancer. Plant Physiol Biochem 48: 621-626.

14. Shin KH, Bae SD, Hong HS, Kim RH, Kang MK, et.al (2011) miR-181a shows tumor suppressive effect against oral squamous cell carcinoma cells by downregulating K-ras. Biochem Biophys Res Commun 404: 896-902.

15. Yang CJ, Shen WG, Liu CJ, Chen YW, Lu HH, et al (2011) miR-221 and miR-222 expression increased the growth and tumorigenesis of oral carcinoma cells. J Oral Pathol Med 40: 560-566

16. Nobili S, Lippi D, Witort E, Donnini M, Bausi L, et al (2009) Natural compounds for cancer treatment and prevention. Pharmacol Res 59: 365-378.

17. Rosenbloom RA, Chaudhary J, Castro-Eschenbach D (2011) Traditional botanical medicine: an introduction. Am J Ther 18 :158-161.

18. Low Dog $\mathrm{T}$ (2009) The use of botanicals during pregnancy and lactation. Altern Ther Health Med 15: 54-58.

19. Baskar AA, Ignacimuthu S, Paulraj GM, Al Numair KS (2010) Chemopreventive potential of beta-Sitosterol in experimental colon cancer model - an in vitro and In vivo study. BMC Complement Altern Med 10:24-34.

20. Gullett NP, Ruhul Amin AR, Bayraktar S, Pezzuto JM, Shin DM, et al (2010) Cancer prevention with natural compounds. Semin Oncol 37 : 258-281.

21. Khan N, Afaq F, Mukhtar H (2008) Cancer chemoprevention through dietary antioxidants: progress and promise. Antioxid Redox Signal 10 : 475-510.

22. Syed DN, Mukhtar H (2011) Botanicals for the prevention and treatment of cutaneous melanoma. Pigment Cell Melanoma Res 24 :688-702.
23. Cronin H, Draelos ZD (2010) Top 10 botanical ingredients in 2010 antiageing creams. J Cosmet Dermatol $9: 218-225$.

24. Donate LE, Blasco MA (2011) Telomeres in cancer and ageing. Philos Trans R Soc Lond B Biol Sci 366: 76-84.

25. Herranz D, Muñoz-Martin M, Cañamero M, Mulero F, Martinez-Pastor B, et al (2010) Sirtl improves healthy ageing and protects from metabolic syndrome-associated cancer. Nat Commun 1:3.

26. Kiyono $\mathrm{T}$ (2007) Molecular mechanisms of cellular senescence and immortalization of human cells. Expert Opin Ther Targets 11 : 1623-1637.

27. Longo VD, Lieber MR, Vijg J (2008) Turning anti-ageing genes against cancer. Nat Rev Mol Cell Biol 9 : 903-910.

28. Svendsen L, Rattan SI, Clark BF (1994) Testing garlic for possible antiageing effects on long-term growth characteristics, morphology and macromolecular synthesis of human fibroblasts in culture. J Ethnopharmacol $43: 125-133$.

29. Noren Hooten N, Abdelmohsen K, Gorospe M, Ejiogu N, Zonderman $A B$, et al (2010) MicroRNA expression patterns reveal differential expression of target genes with age. PLoS One 5: e 10724.

30. Song FJ, Chen KX (2011) Single-nucleotide polymorphisms among microRNA: big effects on cancer. Chin J Cancer 30 :381-391.

31. Kingsley K, Galbraith GM, Herring M, Stowers E, Stewart T, et al (2011) Why not just Google it? An assessment of information literacy skills in a biomedical science curriculum. BMC Med Educ 11:17.

32. Giglia E (2008) To Google or not to Google, this is the question. Eur J Phys Rehabil Med 44 :221-230.

33. Roberts RJ (2001) PubMed Central: The GenBank of the published literature. Proc Natl Acad Sci USA 98 : 381-382.

34. Walters WH Google scholar search performance: comparative recall and precision. Portal Libr Acad 9: 5-24.

35. Kim SY, Hahm CK, Bae CW, Cho HM (2008) Duplicate Publications in Korean medical journals indexed in KoreaMed. J Korean Med Sc 23 : 131-133.

36. Sato H, Genet C, Strehle A, Thomas C, Lobstein A, et al (2007) Antihyperglycemic activity of a TGR5 agonist isolated from Olea europaea. Biochem Biophys Res Commun 362 : 793-798.

37. Grawish ME, Zyada MM, Zaher AR (2010) Inhibition of 4-NQO-induced F433 rat tongue carcinogenesis by oleuropein-rich extract. Med Oncol 28: $1163-1168$

38. Roy MK, Kobori M, Takenaka M, Nakahara K, Shinmoto H, et al (2007) Antiproliferative effect on human cancer cell lines after treatment with nimbolide extracted from an edible part of the neem tree (azadirachta indica). Phytother Res $21: 245-250$.

39. Subapriya R, Bhuvaneswari V, Ramesh V, Nagini S. (2005) Ethanolic leaf extract of neem (Azadirachta indica) inhibits buccal pouch carcinogenesis in hamsters. Cell Biochem Funct $23: 229-238$.

40. Manikandan P, Letchoumy PV, Gopalakrishnan M, Nagini S (2008) Evaluation of Azadirachta indica leaf fractions for in vitro antioxidant potential and in vivo modulation of biomarkers of chemoprevention in the hamster buccal pouch carcinogenesis model. Food Chem Toxicol 46 : 2332-2343.

41. Subapriya R, Bhuvaneswari V, Nagini S (2005) Ethanolic neem (Azadirachta indica) leaf extract induces apoptosis in the hamster buccal pouch carcinogenesis model by modulation of Bcl-2, Bim, caspase 8 and caspase 3. Asian Pac J Cancer Prev. 6 : 515-520.

42. Harish Kumar G, Vidya Priyadarsini R, Vinothini G, Vidjaya Letchoumy P, Nagini S (2010) The neem limonoids azadirachtin and nimbolide inhibit cell proliferation and induce apoptosis in an animal model of oral oncogenesis. Invest New Drugs 28 : 392-401.

43. Priyadarsini RV, Manikandan P, Kumar GH, Nagini S (2009) The neem limonoids azadirachtin and nimbolide inhibit hamster cheek pouch carcinogenesis by modulating xenobiotic-metabolizing enzymes, DNA damage, antioxidants, invasion and angiogenesis. Free Radic Res 43 : 492-504. 
44. Monobe M, Ema K, Tokuda Y, Maeda-Yamamoto M (2010) Enhancement of the phagocytic activity of macrophage-like cells with a crude polysaccharide derived from green tea (Camellia sinensis) extract. Biosci Biotechnol Biochem $74: 1306-1308$.

45. Li N, Chen X, Liao J, Yang G, Wang S, et al (2002) Inhibition of 7,12dimethylbenz[a]anthracene (DMBA)-induced oral carcinogenesis in hamsters by tea and curcumin. Carcinogenesis $23: 1307-1313$.

46. Srinivasan P, Suchalatha S, Babu PV, Devi RS, Narayan S, et al (2008) Chemopreventive and therapeutic modulation of green tea polyphenols on drug metabolizing enzymes in 4-nitroquinoline 1-oxide induced oral cancer. Chem Biol Interact $172: 224-234$.

47. Chandra Mohan KV, Hara Y, Abraham SK, Nagini S (2005) Comparative evaluation of the chemopreventive efficacy of green and black tea polyphenols in the hamster buccal pouch carcinogenesis model. Clin Biochem $38: 879-886$.

48. Babich H, Krupka ME, Nissim HA, Zuckerbraun HL (2005) Differential in vitro cytotoxicity of (-)-epicatechin gallate (ECG) to cancer and normal cells from the human oral cavity. Toxicol In vitro $19: 231-242$.

49. Ho YC, Yang SF, Peng CY, Chou MY, Chang YC (2007) Epigallocatechin-3-gallate inhibits the invasion of human oral cancer cells and decreases the productions of matrix metalloproteinases and urokinase-plasminogen activator. J Oral Pathol Med 36 : 588-593.

50. Kato K, Long NK, Makita H, Toida M, Yamashita T, et al (2008) Effects of green tea polyphenol on methylation status of RECK gene and cancer cell invasion in oral squamous cell carcinoma cells. Br J Cancer 99 : 647-654.

51. Tsao AS, Liu D, Martin J, Tang XM, Lee JJ, et al (2009) Phase II randomized, placebo-controlled trial of green tea extract in patients with high-risk oral premalignant lesions. Cancer Prev Res (Phila) 2 : 931-941.

52. Halder A, Raychowdhury R, Ghosh A, De M (2005) Black tea (Camellia sinensis) as a chemopreventive agent in oral precancerous lesions. J Environ Pathol Toxicol Oncol. 24 :141-144.

53. Letchoumy PV, Chandra Mohan KV, Kumaraguruparan R, Hara Y, Nagini S (2006) Black tea polyphenols protect against 7,12 dimethylbenz[a]anthracene-induced hamster buccal pouch carcinogenesis. Oncol Res $16: 167-178$.

54. Letchoumy PV, Mohan KV, Prathiba D, Hara Y, Nagini S (2007) Comparative evaluation of antiproliferative, antiangiogenic and apoptosis inducing potential of black tea polyphenols in the hamster buccal pouch carcinogenesis model. J Carcinog 6:19.

55. Vidjaya Letchoumy P, Chandra Mohan KV, Stegeman JJ, Gelboin HV, Hara Y, et al (2008) Pretreatment with black tea polyphenols modulates xenobiotic-metabolizing enzymes in an experimental oral carcinogenesis model. Oncol Res 17 : 75-85.

56. Chandra Mohan KV, Devaraj H, Prathiba D, Hara Y, Nagini S (2006) Antiproliferative and apoptosis inducing effect of lactoferrin and black tea polyphenol combination on hamster buccal pouch carcinogenesis. Biochim Biophys Acta 1760 : 1536-1544.

57. Gonzalez de Mejia E, Song YS, Ramirez-Mares MV, Kobayashi H (2005) Effect of yerba mate (ilex paraguariensis) tea on topoisomerase inhibition and oral carcinoma cell proliferation. J Agric Food Chem 53 : 1966-1973.

58. Pandey R, Verma RK, Singh SC, Gupta MM (2003) 4alphamethyl-24beta-ethyl-5alpha-cholesta-14,25-dien-3beta-ol and 24betaethylcholesta-5, 9(11), 22E-trien-3beta-ol, sterols from clerodendrum inerme. Phytochemistry 63: 415-420.

59. Manoharan S, Kavitha K, Senthil N, Renju GL (2006) Evaluation of anticarcinogenic effects of clerodendron inerme on 7,12-dimethylbenz(a) anthracene-induced hamster buccal pouch carcinogenesis. Singapore Med J 47:1038-1043.

60. Kataria H, Shah N, Kaul SC, Wadhwa R, Kaur G (2011) Water extract of ashwagandha leaves limits proliferation and migration, and induces differentiation in glioma cells. Evid Based Complement Alternat Med 267614

61. Bargagna-Mohan P, Hamza A, Kim YE, Khuan Abby Ho Y, Mor-Vaknin $\mathrm{N}$, et al (2007) The tumor inhibitor and antiangiogenic agent withaferin
A targets the intermediate filament protein vimentin. Chem Biol 14 : 623-634.

62. Panjamurthy K, Manoharan S, Balakrishnan S, Suresh K, Nirmal MR, et al (2008) Protective effect of withaferin-A on micronucleus frequency and detoxication agents during experimental oral carcinogenesis. Afr J Tradit Complement Altern Med $6: 1-8$.

63. Manoharan S, Panjamurthy K, Pugalendi P, Balakrishnan S, Rajalingam $\mathrm{K}$, et al (2008) Protective role of withaferin-A on red blood cell integrity during 7,12-dimethylbenz[a] anthracene induced oral carcinogenesis. Afr J Tradit Complement Altern Med 6 :94-102.

64. Aggarwal BB, Kumar A, Bharti AC (2003) Anticancer potential of curcumin: preclinical and clinical studies. Anticancer Res $23: 363-398$.

65. White B (2007) Ginger: an overview. Am Fam Physician 75 : 1689-1691.

66. Elattar TM, Virji AS (2000) The inhibitory effect of curcumin, genistein, quercetin and cisplatin on the growth of oral cancer cells in vitro. Anticancer Res $20: 1733-1738$.

67. Rinaldi AL, Morse MA, Fields HW, Rothas DA, Pei P, et al (2002) Curcumin activates the aryl hydrocarbon receptor yet significantly inhibits (-)-benzo(a)pyrene-7R-trans-7,8-dihydrodiol bioactivation in oral squamous cell carcinoma cells and oral mucosa. Cancer Res 62 : 5451-5456.

68. Atsumi T, Tonosaki K, Fujisawa S (2006) Induction of early apoptosis and ROS-generation activity in human gingival fibroblasts (HGF) and human submandibular gland carcinoma (HSG) cells treated with curcumin. Arch Oral Biol 51:913-921.

69. Manoharan S, Balakrishnan S, Menon VP, Alias LM, Reena AR (2009) Chemopreventive efficacy of curcumin and piperine during 7,12dimethylbenz[a]anthracene-induced hamster buccal pouch carcinogenesis. Singapore Med J 50:139-146.

70. Garg R, Ingle A, Maru G (2008) Dietary turmeric modulates DMBAinduced p21ras, MAP kinases and AP-1/NF kappa B pathway to alter cellular responses during hamster buccal pouch carcinogenesis. Toxicol Appl Pharmacol 232 : 428-439.

71. Shin HK, Kim J, Lee EJ, Kim SH (2010) Inhibitory effect of curcumin on motility of human oral squamous carcinoma YD-10B cells via suppression of ERK and NF-kappaB activations. Phytother Res 24 : 577-582.

72. Khater DS (2010) The influence of ginger as a chemopreventive agent on proliferation and apoptosis in chemically induced oral carcinogenesis. Nature and Science $8: 44-51$

73. Ilavarasan R, Vasudevan M, Anbazhagan S, Venkataraman S (2003) Antioxidant activity of thespesia populnea bark extracts against carbon tetrachloride-induced liver injury in rats. J Ethnopharmacol 87:227-230.

74. Dhanarasu S, Al-hazimi AM, Sethuraman P, Selvam M (2010) Chemopreventive and antilipidperoxidative potential of thespesia populnea (L.) on experimental buccal pouch carcinogenesis. Ibnosina J Med BS. $2: 269-277$.

75. Rodrigo KA, Rawal Y, Renner RJ, Schwartz SJ, Tian Q, et al (2006) Suppression of the tumorigenic phenotype in human oral squamous cell carcinoma cells by an ethanol extract derived from freeze-dried black raspberries. Nutr Cancer 54 : 58-68.

76. Casto BC, Kresty LA, Kraly CL, Pearl DK, Knobloch TJ, et al (2002) Chemoprevention of oral cancer by black raspberries. Anticancer Res 22 : 4005-4015.

77. Han C, Ding H, Casto B, Stoner GD, D'Ambrosio SM (2005) Inhibition of the growth of premalignant and malignant human oral cell lines by extracts and components of black raspberries. Nutr Cancer 51 :207-217.

78. Mallery SR, Stoner GD, Larsen PE, Fields HW, Rodrigo KA, et al (2007) Formulation and in vitro and in-vivo evaluation of a mucoadhesive gel containing freeze dried black raspberries: implications for oral cancer chemoprevention. Pharm Res 24 : 728-737.

79. Mallery SR, Zwick JC, Pei P, Tong M, Larsen PE, et al (2008) Topical application of a bioadhesive black raspberry gel modulates gene expression and reduces cyclooxygenase 2 protein in human premalignant oral lesions. Cancer Res 68 :4945-4957. 
80. Dugoua JJ, Seely D, Perri D, Mills E, Koren G (2008) Safety and efficacy of cranberry (vaccinium macrocarpon) during pregnancy and lactation. Can J Clin Pharmacol 15: e 80-86.

81. Li MH, Jang JH, Sun B, Surh YJ (2004) Protective effects of oligomers of grape seed polyphenols against beta-amyloid-induced oxidative cell death. Ann N Y Acad Sci $1030: 317-329$.

82. Stanković M, Tesević V, Vajs V, Todorović N, Milosavljević S, et al (2008) Antioxidant properties of grape seed extract on human lymphocyte oxidative defence. Planta Med $74: 730-735$.

83. Hayasaka Y, Waters EJ, Cheynier V, Herderich MJ, Vidal S (2003) Characterization of proanthocyanidins in grape seeds using electrospray mass spectrometry. Rapid Commun Mass Spectrom 17:9-16.

84. Shirataki Y, Kawase M, Saito S, Kurihara T, Tanaka W, et al (2000) Selective cytotoxic activity of grape peel and seed extracts against oral tumor cell lines. Anticancer Res 20:423-426.

85. Chatelain K, Phippen S, McCabe J, Teeters CA, O'Malley S, et al (2008) Cranberry and grape seed extracts inhibit the proliferative phenotype of oral squamous cell carcinomas. Evid Based Complement Alternat Med

86. Luengwilai K, Fiehn OE, Beckles DM (2010) Comparison of leaf and fruit metabolism in two tomato (solanum lycopersicum L.) genotypes varying in total soluble solids. J Agric Food Chem 58:11790-11800.

87. Bhuvaneswari V, Rao KS, Nagini S (2004) Altered expression of anti and proapoptotic proteins during chemoprevention of hamster buccal pouch carcinogenesis by tomato and garlic combination. Clin Chim Acta 350:65-72.

88. Bhuvaneswari V, Abraham SK, Nagini S (2005) Combinatorial antigenotoxic and anticarcinogenic effects of tomato and garlic through modulation of xenobiotic-metabolizing enzymes during hamster buccal pouch carcinogenesis. Nutrition 21:726-731.

89. Bhuvaneswari V, Velmurugan B, Balasenthil S, Ramachandran CR, Nagini S (2001) Chemopreventive efficacy of lycopene on 7,12dimethylbenz[a]anthracene-induced hamster buccal pouch carcinogenesis. Fitoterapia 72:865-874.

90. Livny O, Kaplan I, Reifen R, Polak-Charcon S, Madar Z, et al (2002) Lycopene inhibits proliferation and enhances gap-junction communication of KB-1 human oral tumor cells. J Nutr 132:3754-3759.

91. Singh M, Krishanappa R, Bagewadi A, Keluskar V (2004) Efficacy of oral lycopene in the treatment of oral leukoplakia. Oral Oncol 40:591-596.

92. Bhuvaneswari V, Velmurugan B, Nagini S (2004) Dose-response effect of tomato paste on 7,12-dimethylbenz[a]anthracene-induced hamster buccal pouch carcinogenesis. J Exp Clin Cancer Res 23:241-249.

93. Aviello G, Abenavoli L, Borrelli F, Capasso R, Izzo AA, et al (2009) Garlic: empiricism or science? Nat Prod Commun 4:1785-1796.

94. Balasenthil S, Nagini S (2000) Inhibition of 7,12dimethylbenz[a]anthracene-induced hamster buccal pouch carcinogenesis by S-allylcysteine. Oral Oncol 36:382-386.

95. Balasenthil S, Ramachandran CR, Nagini S (2001) S-allylcysteine, a garlic constituent, inhibits 7,12-dimethylbenz[a]anthracene-induced hamster buccal pouch carcinogenesis. Nutr Cancer 40:165-172.

96. Balasenthil S, Rao KS, Nagini S (2002) Garlic induces apoptosis during 7,12-dimethylbenz[a]anthracene-induced hamster buccal pouch carcinogenesis. Oral Oncol 38:431-436.

97. Balasenthil S, Rao KS, Nagini S (2003) Retinoic acid receptor-beta mRNA expression during chemoprevention of hamster cheek pouch carcinogenesis by garlic. Asia Pac J Clin Nutr 12:215-218.

98. Tang FY, Chiang EP, Chung JG, Lee HZ, Hsu CY (2009) S-allylcysteine modulates the expression of E-cadherin and inhibits the malignant progression of human oral cancer. J Nutr Biochem 20:1013-1020.

99. Balasenthil S, Rao KS, Nagini S (2002) Altered cytokeratin expression during chemoprevention of experimental hamster buccal pouch carcinogenesis by garlic. J Oral Pathol Med 31:142-146.

100. Balasenthil S, Arivazhagan S, Nagini S (2000) Garlic enhances circulatory antioxidants during 7, 12-dimethylbenz[a]anthracene-induced hamster buccal pouch carcinogenesis. J Ethnopharmacol 72:429-433.
101. Balasenthil S, Ramachandran CR, Nagini S (2001) Prevention of 4nitroquinoline 1-oxide-induced rat tongue carcinogenesis by garlic. Fitoterapia 72:524-531.

102. Koul IB, Kapil A (1993) Evaluation of the liver protective potential of piperine, an active principle of black and long peppers. Planta Med. 59:413-417.

103. Krishnakumar N, Manoharan S, Palaniappan PR, Venkatachalam P, Manohar MG (2009) Chemopreventive efficacy of piperine in 7,12dimethyl benz [a] anthracene (DMBA)-induced hamster buccal pouch carcinogenesis: an FT-IR study. Food Chem Toxicol 47:2813-2820.

104. Tanaka T, Kohno H, Sakata K, Yamada Y, Hirose Y, et al (2002) Modifying effects of dietary capsaicin and rotenone on 4-nitroquinoline 1-oxide-induced rat tongue carcinogenesis. Carcinogenesis 23:1361-1367.

105. Sun A, Chiang CP (2001) Levamisole and/or Chinese medicinal herbs can modulate the serum level of squamous cell carcinoma associated antigen in patients with erosive oral lichen planus. J Oral Pathol Med 30:542-548.

106. Chu Q, Satoh K, Kanamoto T, et al (2009) Antitumor potential of three herbal extracts against human oral squamous cell lines. Anticancer Res. 29:3211-3219.

107. Liao PH, Chen SL, Shih HC, Chou MY (2005) Induction of apoptosis in human oral cancer cell lines, OC2 and TSCCa, by Ching waysan. Am J Chin Med 33:21-27.

108. Jiang C, Ye D, Qiu W, Zhang X, Zhang Z, et al (2007) Response of lymphocyte subsets and cytokines to shenyang prescription in SpragueDawley rats with tongue squamous cell carcinomas induced by 4 NQO. BMC Cancer 7:40.

109. Sun Z, Guan X, Li N, Liu X, Chen X (2010) Chemoprevention of oral cancer in animal models, and effect on leukoplakias in human patients with Zeng sheng ping, a mixture of medicinal herbs. Oral Oncol 46:105-110.

110. Zhou Z, Zhang S, Hua L, Zhong W, Jin Z (2000) Leukoplakia and angiopoiesis resistance of Herba Erigerontis. Chin J Dent Res 3:56-62.

111. Xu YZ, Qiu YL, An ZG, Yang FY (2010) Role of the Chinese herbal medicine Xian huayin on the reversal of premalignant mucosal lesions in the golden hamster buccal pouch. Int J Oral Sci 2:53-58.

112. Lee HJ, Son DH, Lee SK, Lee J, Jun CD, et al (2006) Extract of Coptidis rhizoma induces cytochrome-c dependent apoptosis in immortalized and malignant human oral keratinocytes. Phytother Res 20:773-779.

113. Yun YG, Jeon BH, Lee JH, Lee SK, Lee HJ, et al (2008) Verticinone induces cell cycle arrest and apoptosis in immortalized and malignant human oral keratinocytes. Phytother Res 22:416-423.

114. Xiao B, Guo J, Liu D, Zhang S (2007) Aloe-emodin induces in vitro $\mathrm{G} 2 / \mathrm{M}$ arrest and alkaline phosphatase activation in human oral cancer KB cells. Oral Oncol 43:905-910.

115. Chen YY, Chiang SY, Lin JG, Ma YS, Liao CL, et al (2010) Emodin, aloeemodin and rhein inhibit migration and invasion in human tongue cancer SCC-4 cells through the inhibition of gene expression of matrix metalloproteinase-9. Int J Oncol. 36:1113-1120.

116. Min R, Tong J, Wenjun Y, Wenhu D, Xiaojian Z, et al (2008) Growth inhibition and induction of apoptosis in human oral squamous cell carcinoma Tca-8113 cell lines by Shikonin was partly through the inactivation of NF-kappa B pathway. Phytother Res 22:407-415.

117. Hayashi T, Hayashi K, Maeda M, Kojima I (1996) Calcium spirulan, an inhibitor of enveloped virus replication, from a blue-green alga spirulina platensis. J Nat Prod 59:83-87.

118. Grawish ME (2008) Effects of Spirulina platensis extract on Syrian hamster cheek pouch mucosa painted with 7,12dimethylbenz[a]anthracene. Oral Oncol 44:956-962.

119. Grawish ME, Zaher AR, Gaafar AI, Nasif WA (2010) Long-term effect of Spirulina platensis extract on DMBA-induced hamster buccal pouch carcinogenesis (immunohistochemical study). Med Oncol 27:20-28.

120. Mathew S, Abraham TE (2004) Ferulic acid: an antioxidant found naturally in plant cell walls and feruloyl esterases involved in its release and their applications. Crit Rev Biotechnol 24:59-83. 
121. Balakrishnan S, Menon VP, Manoharan S (2008) Ferulic acid inhibits 7,12-dimethylbenz[a]anthracene-induced hamster buccal pouch carcinogenesis. J Med Food 11:693-700.

122. Manoharan S, Vasanthaselvan M, Silvan S, Baskaran N, Kumar Singh A, et al (2010) Carnosic acid: a potent chemopreventive agent against oral carcinogenesis. Chem Biol Interact 188:616-622.

123. Craig WJ (1999) Health-promoting properties of common herbs. Am J Clin Nutr 70:491-499.

124. Ho YT, Yang JS, Lu CC, Chiang JH, Li TC, et al (2009) Berberine inhibits human tongue squamous carcinoma cancer tumor growth in a murine xenograft model. Phytomedicine 16:887-890.

125. Lin CC, Yang JS, Chen JT, Fan S, Yu FS, et al (2007) Berberine induces apoptosis in human HSC-3 oral cancer cells via simultaneous activation of the death receptor-mediated and mitochondrial pathway. Anticancer Res 27:3371-3378.

126. Ho YT, Yang JS, Li TC, Lin JJ, Lin JG, et al (2009) Berberine suppresses in vitro migration and invasion of human SCC-4 tongue squamous cancer cells through the inhibitions of FAK, IKK, NF kappa B, u-PA and MMP-2 and -9. Cancer Lett 279:155-162.

127. Cassileth BR, Heitzer M, Wesa K (2009) The public health impact of herbs and nutritional supplements. Pharm Biol 47:761-767.

128. Marcus DM, Grollman AP (2006) Science and government. Review for NCCAM is overdue. Science 313:301-302.

129. Das A, Mondal TK (2010) Computational identification of conserved microRNAs and their targets in tea (camellia sinensis). Am J Plant Sci. 1:77-86.

130. Prabu GR, Mandal AK (2010) Computational identification of miRNAs and their target genes from expressed sequence tags of tea (Camellia sinensis). Genomics Proteomics Bioinformatics 8:113-121.

131. Lazzari B, Caprera A, Cestaro A, Merelli I, Del Corvo M, et al (2009) Ontology-oriented retrieval of putative microRNAs in Vitis vinifera via GrapeMiRNA: a web database of de novo predicted grape microRNAs. BMC Plant Biol 9:82.

132. Pantaleo V, Szittya G, Moxon S, Miozzi L, Moulton V, et al (2010) Identification of grapevine microRNAs and their targets using highthroughput sequencing and degradome analysis. Plant J 62:960-976.

133. Faccioli P, Stanca AM, Morcia C, Alberici R, Terzi V (2010) Identification of a set of widely expressed genes in grape (Vitis vinifera L.) and its functional characterisation: a multi-evidence based study. Vitis 49:175-179.

134. Mica E, Piccolo V, Delledonne M, Ferrarini A, Pezzotti M, et al (2010) Correction: High throughput approaches reveal splicing of primary microRNA transcripts and tissue specific expression of mature microRNAs in vitis vinifera. BMC Genomics 11:109.

135. Zhang J, Zeng R, Chen J, Liu X, Liao Q (2008) Identification of conserved microRNAs and their targets from Solanum lycopersicum Mill. Gene 423:1-7.

136. Gu M, Xu K, Chen A, Zhu Y, Tang G, et al (2010) Expression analysis suggests potential roles of microRNAs for phosphate and arbuscular mycorrhizal signalling in solanum lycopersicum. Physiol Plant 138:226-237.

137. Zhang X, Zou Z, Gong P, Zhang J, Ziaf K, et al (2011) Over-expression of microRNA169 confers enhanced drought tolerance to tomato. Biotechnol Lett 33:403-409.

138. Buxdorf K, Hendelman A, Stav R, Lapidot M, Ori N, et al (2010) Identification and characterization of a novel miR159 target not related to MYB in tomato. Planta 232:1009-1022.

139. Berger Y, Harpaz-Saad S, Brand A, Melnik H, Sirding N, et al (2009) The NAC-domain transcription factor GOBLET specifies leaflet boundaries in compound tomato leaves. Development 136:823-832.

140. Ori N, Cohen AR, Etzioni A, Brand A, Yanai O, et al (2007) Regulation of LANCEOLATE by miR319 is required for compound-leaf development in tomato. Nat Genet 39:787-91.

141. Naqvi AR, Choudhury NR, Mukherjee SK, Haq QM (2011) In silico analysis reveals that several tomato microRNA/microRNA ? sequences exhibit propensity to bind to tomato leaf curl virus (ToLCV) associated genomes and most of their encoded open reading frames (ORFs). Plant Physiol Biochem 49:13-17.

142. Naqvi AR, Haq QM, Mukherjee SK (2010) MicroRNA profiling of tomato leaf curl New Delhi virus (tolcndv) infected tomato leaves indicates that deregulation of mir159/319 and mir172 might be linked with leaf curl disease. Virol J 7:281.

143. Cillo F, Mascia T, Pasciuto MM, Gallitelli D (2009) Differential effects of mild and severe Cucumber mosaic virus strains in the perturbation of microRNA-regulated gene expression in tomato map to the 3 ' sequence of RNA 2. Mol Plant Microbe Interact 22:1239-1249.

144. Li H, Dong Y, Sun Y, Zhu E, Yang J, et al (2011) Investigations of the microRNAs in safflower seed, leaf and petal by high-throughput sequencing. Planta 233:611-619.

145. Yao Y, Guo G, Ni Z, Sunkar R, Du J, et al (2007) Cloning and characterization of microRNAs from wheat (Triticum aestivum L.). Genome Biol 8:R96.

146. Dryanova A, Zakharov A, Gulick PJ (2008) Data mining for miRNAs and their targets in the Triticeae. Genome 51:433-443.

147. Li Y, Li W, Jin YX (2005) Computational identification of novel family members of microRNA genes in Arabidopsis thaliana and Oryza sativa. Acta Biochim Biophys Sin (Shanghai) 37:75-87.

148. Huang SQ, Peng J, Qiu CX, Yang ZM (2009) Heavy metal-regulated new microRNAs from rice. J Inorg Biochem 103:282-287.

149. Sanan-Mishra N, Kumar V, Sopory SK, Mukherjee SK (2009) Cloning and validation of novel miRNA from basmati rice indicates cross talk between abiotic and biotic stresses. Mol Genet Genomics 282:463-474.

150. Wu L, Zhang Q, Zhou H, Ni F, Wu X, et al (2009) Rice MicroRNA effector complexes and targets. Plant Cell 21:3421-3435.

151. Fix LN, Shah M, Efferth T, Farwell MA, Zhang B (2010) MicroRNA expression profile of MCF-7 human breast cancer cells and the effect of green tea polyphenon-60. Cancer Genomics Proteomics 7:261-277.

152. Tsang WP, Kwok TT (2010) Epigallocatechin gallate up-regulation of miR-16 and induction of apoptosis in human cancer cells. J Nutr Biochem 21:140-146.

153. Ahn JI, Jeong MJ, Shin HJ, Kim HS, Chung HJ, et al (2010) Changes of miRNA and mRNA expression in HepG2 cells treated by epigallocatechin gallate. Mol Cell Toxicol 6:169-177.

154. Siddiqui IA, Asim M, Hafeez BB, Adhami VM, Tarapore RS, et al (2011) Green tea polyphenol EGCG blunts androgen receptor function in prostate cancer. FASEB J 25:1198-1207.

155. Zhang J, Du Y, Wu C, Ren X, Ti X, et al (2010) Curcumin promotes apoptosis in human lung adenocarcinoma cells through miR-186* signaling pathway. Oncol Rep 24:1217-1223.

156. Zhang J, Zhang T, Ti X, et al (2010) Curcumin promotes apoptosis in A549/DDP multidrug-resistant human lung adenocarcinoma cells through an miRNA signaling pathway. Biochem Biophys Res Commun 399:1-6.

157. Yang J, Cao Y, Sun J, Zhang Y (2010) Curcumin reduces the expression of Bcl-2 by upregulating miR-15a and miR-16 in MCF-7 cells. Med Oncol 27:1114-1118.

158. Ali S, Ahmad A, Banerjee S, Padhye S, Dominiak K, et al (2010) Gemcitabine sensitivity can be induced in pancreatic cancer cells through modulation of miR-200 and miR-21 expression by curcumin or its analogue CDF. Cancer Res 70:3606-3617.

159. Sun M, Estrov Z, Ji Y, Coombes KR, Harris DH, et al (2008) Curcumin (diferuloylmethane) alters the expression profiles of microRNAs in human pancreatic cancer cells. Mol Cancer Ther 7:464-473.

160. Mudduluru G, George-William JN, Muppala S, Asangani IA, Kumarswamy R, et al (2011) Curcumin regulates miR-21 expression and inhibits invasion and metastasis in colorectal cancer. Biosci Rep 31:185-197.

161. Cui JG, Li YY, Zhao Y, Bhattacharjee S, Lukiw WJ (2010) Differential regulation of interleukin-1 receptor-associated kinase-1 (IRAK-1) and 
Citation: Grawish ME, Wagner M, Vicinus B, Jack MJ, Richards T, et al. (2014) Has Anyone so far Bridged the Gap between microRNA, Botanicals and Oropharyngeal Squamous Cell Carcinoma?. Altern Integ Med 3: 163. doi:10.4172/2327-5162.1000163

Page 11 of 11

IRAK-2 by microRNA-146a and NF kappa B in stressed human astroglial cells and in Alzheimer disease. J Biol Chem 285:38951-38960.

162. Li YY, Cui JG, Hill JM, Bhattacharjee S, Zhao Y, et al (2011) Increased expression of miRNA-146a in Alzheimer's disease transgenic mouse models. Neurosci Lett 487:94-98.

163. Zhu M, Wang N, Tsao SW, Yuen MF, Feng Y, et al (2011) Up-regulation of microRNAs, miR21 and miR23a in human liver cancer cells treated with Coptidis rhizome aqueous extract. Exp Ther Med 2: 27-32.

164. Do CB, Foo CS, Batzoglou S (2008) A max-margin model for efficient simultaneous alignment and folding of RNA sequences. Bioinformatics 24:168-176.

165. Gruber AR, Lorenz R, Bernhart SH, Neuböck R, Hofacker IL (2008) The Vienna RNA Websuite. Nucleic Acids Res 36: W 70-74.

166. Hofacker IL, Stadler PF (2006) Memory efficient folding algorithms for circular RNA secondary structures. Bioinformatics 22:1172-1176.

167. Boehm K, Borrelli F, Ernst E, Habacher G, Hung SK, et al (2009) Green tea (Camellia sinensis) for the prevention of cancer. Cochrane Database Syst Rev CD005004.
168. Dhillon N, Aggarwal BB, Newman RA, Wolff RA, Kunnumakkara AB, et al (2008) Phase II trial of curcumin in patients with advanced pancreatic cancer. Clin Cancer Res. 14:4491-4499.

169. Sharma RA, Euden SA, Platton SL, Cooke DN, Shafayat A, et al (2004) Phase I clinical trial of oral curcumin: biomarkers of systemic activity and compliance. Clin Cancer Res 10:6847-6854.

170. Williamson EM (2002) Major Herbs of Ayurveda. (1st edn) Churchill Livingstone Oxford UK

171. Schwarz S, Obermüller-Jevic UC, Hellmis E, Koch W, Jacobi G, et al (2008) Lycopene inhibits disease progression in patients with benign prostate hyperplasia. J Nutr 138:49-53.

172. Van Patten CL, de Boer JG, Tomlinson Guns ES (2008) Diet and dietary supplement intervention trials for the prevention of prostate cancer recurrence: a review of the randomized controlled trial evidence. J Urol 180:2314-2321.

173. Fleischauer AT, Poole C, Arab L (2000) Garlic consumption and cancer prevention: meta-analyses of colorectal and stomach cancers. Am J Clin Nutr 72:1047-1052. 